\title{
RE-THINKING OTHER CLAIMANTS TO PROPHETHOOD: the Case of Umayya ibn Abi Ṣalt ${ }^{1}$
}

\author{
Al Makin \\ The Faculty of Theology, State Islamic University (UIN) Sunan Kalijaga \\ Yogyakarta, Indonesia
}

\begin{abstract}
This article questions the domination of the prophethood of Mubammad in the narrative of the seventh century of the Arabian Peninsula presented by both Muslim and Western scholars. There were many other claimants to prophethood, who are ignored in Muslim and Western sources. In this vein, this article deals with Umayya ibn Abi Salt, a poet who claimed prophethood. Umayya's short biography, collections of his poems (diwan) and, and examples of his poems are discussed.
\end{abstract}

Keywords: prophethood, qur'ān, Umayya, revelation, sira, diwān.

${ }^{1}$ The draft of this paper was originally presented at the colloquium at the IKGF (The International Consortium for Research in the Humanities) "Dynamics in the History of Religions between Asia and Europe” Ruhr University, Bochum, Germany, on 23 November, 2009. Thus, I would like to thank the Consortium for this opportunity, which for me is a golden one to learn more from others and from those whose backgrounds and interests of study are different. My thanks should also go to all fellows and friends, Damien Janos, Jason Neelis, Abishekh Sing Amar, and those whose names cannot be mentioned here, who in the last months have also shaped my mind. I read Umayya ibn Abi Salt's poems at least in three occasions in the IKGF seminars and workshops: on the Shcickshal workshop, an IKGF conference, KDVR/(Kongress der Deutschen Vereinigung für Religionswissenschaft), and Sateorology workshop. 


\section{A. Introduction}

\section{Issues in Narrating the Accounts of the Seventh Century of Arabian Peninsula: the centrality of Mubammad, the Qur'an, and Islam}

The narrative of the sixth and seventh centuries in the Arabian peninsula has been dominated by the prophethood of Muhammad, Islam, and the Qur'an. Muslim and Western sources have offered more or less this same pattern of narration. While treating Muhammad as the central figure, the other figures, who also claimed prophethood, receive too little attention. However, it is hard to pinpoint the causes of this problem. This seems like what Foucault called discourse, where a certain powerful stream has compelled all of us to subscribe to the same view. Many generations of both Muslim and Western scholarship, have inherited this common view. Various sources portray Muhammad as the only prophet, the heir of all revealed religions (din samainn), who brought Islam, the final religion, revealed the Qur'an, and built the Islamic umma (community) in Medina. No other claimant to prophethood has come into the spotlight.

The primary traditional sources, e.g. sira (e.g. written by Ibn Ishāa $)^{2}$ devote hundreds of pages to the story of Muhammad, from his genealogy, childhood, his appointment as the prophet, death, companions, campaigns, etc. According to this worldview, the Arabian peninsula, even the world, centers on the prophethood of Muhammad. This stance is supported by later Muslim literature, i.e. in sufism, dala'ìl (proofs of prophethood), ijāa al-Qur'an (inimitability of the Qur'an), badith (tradition), fadàil (excellences), fiqh (jurisprudence), ethics (akblāq), to historiography (sira, tabaqät, and tärikh).

The centrality of the figure of Muhammad is not only found in the genres of literature (adab), but also in constructing history (tärik $h$ ). In various genres of literature, Muhammad has been praised for his perfection, serving as insän kamil. In the tärikh, this universe is centered

${ }^{2}$ Ibn Hishām, al-Sirra al-Nabawiyya, ed. Muștafā al-Saqā, Ibrāhīm al-Abyārī and 'Abd al-Hāfiz Shalbi (Cairo: Shirka wa Matba'a al-Bābỉ Muștafāa al-Halabi wa Awlāduh, 1375/1955); trans. A. Guillaume., The Life of Muhammad, a Translation of Ishāà's Sirat Rasūl Allāh (Karachi: Oxford University Press, 1996). 


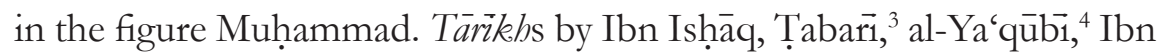
al-Athirr, ${ }^{5}$ Ibn Kathir, ${ }^{6}$ Balādhuri ${ }^{7}$, al-Nuwayri, ${ }^{8}$ etc present the creation of the universe by God, history of kings and prophets, with the ultimate aim that all accounts support the prophethood of Muhammad.

The following is an account of the prophethood of Hūd, a nonBiblical Arabian prophet, as al-Kisā̄i tells us:

When Hūd was forty years old, God spoke to him, saying, "O Hūd, I have selected thee as a prophet and have made thee a messenger to the tribe 'Ad. Go therefore to them and fear them not. Call upon them to witness that there is no god but I alone, who have no partner, and that thou art my servant and my messenger?.

The following is also the appointment of Șâlih, another non Biblical prophet:

When Ṣaliḥ was forty years of age, Gabriel descended to him and gave him the tidings of his apostleship. "Go to Thamūd," he said, "and command them to say that there is no god but God and that you, Șaliḥ, are the servant and apostle of God. Also command them to cease worshipping idols!"10.

As Albrecht Noth ${ }^{11}$ warns us, the two descriptions above are typical topos, for echoing the sira's theme. Both prophets, Șălih and Hūd, are portrayed in the same way as Muhammad was, appointed as the messenger of God, according to sira, when he was forty, to the tribe of Quraysh, who worshipped idols. The Prophet taught monotheism.

${ }^{3}$ al-Ṭabarì, Târikh al-Rusul wa'-Muluk, ed. Muhammad Abū al-Faḍl Ibrāhìm (Cairo: Dār al-Ma‘ārif, 1962).

${ }^{4}$ Ya'qū $\overline{\overline{b i}}$, Târikeh al-Ya'qūbi (Najaf: al-Haydariyya, 1384/1964).

${ }^{5}$ Ibn al-Athir, al-Kāmil fi'l-Tärikeh (Beirut: Dār Șādir, 1385/1965).

${ }^{6}$ Ibn Kathir, al-Bidāya wa'-Nihāya (Beirut: Maktaba al-Ma‘āirif, 1966).

${ }^{7}$ Al-Balādhurì, Kitāb Futūḥ al-Buldān, ed. Șalāḥ al-Dỉn al-Munajjid (Cairo: Maktabat al-Nahḍa al-Mișriyya, n.d.).

${ }^{8}$ Al-Nuwayrì, Nihāyat al-Arab fi Fuñ̄n al-Adab, ed. Muhammad Abū Fạ̣l Ibrāhìm (Cairo: al-Hay’a al-Mișriyya al-`Āmma li'l-Kitāb, 1975).

${ }^{9}$ al-Kisā’r, Qisas al-'Anbiyā, ed. I. Eisenberg (Leiden: Brill, 1922-3), trans. W. M. Thackson Jr. as The Tales of the Prophet of al-Kisäi (Boston: Twayne Publishers, 1978) 111.

${ }^{10}$ al-Kisāsi, The Tales, p. 120.

${ }^{11}$ Albrecht Noth, Quellenkritische Studien zu Themen, Formen und Tendenzen Frühislmischer Geschichtüberlieferung, Teil 1: Themen und Formen (Bonn: Selbtsverlag des Orientalischen Seminars der Unviersität Bonn, 1973), pp. 71-4. 
Now we are dealing with the centrality of the Qur'an. Numerous texts from early and later Muslim literature (ijaz literature) have defended the miracle of the Qur'an, which is seen as unmatched in terms of rhetoric, language, wordings, structure, and content. According to this doctrine, nobody can produce writings whose quality is equal to that of the Qur'an, much less surpass it. ${ }^{12}$ According to the doctrine of sarfa, formulated and supported by many Mu'tazilite thinkers such as Abu Hudhayl, al-Naz̧āam, and al-Jāhiz, God has taken away_or at least weakened—man's ability to rival the Qur'an.

Thus, the sole prophethood of Muhammad, the superiority of the Qur'an, and the religion of Islam has dominated the narration. Other prophets, other qur'ans/readings (what I call qur'an here refers to any other oral traditions, borrowing Richard Bell's explanation), ${ }^{13}$ and other cults are overlooked. Indeed, I would like to submit to you now that there was more than one prophet, one qur'an, one mosque, and one banif movements during the emergence of Islam.

\section{The Finality of Muhammad's Prophethood (Khätam)}

According to the doctrine of khatam, Muhammad is the final prophet, and no prophet comes after him. He sealed all pervious prophets. This argument is developed in the dala'il (proofs of prophethood) literature. However, upon my reading of many collections of hadith e.g. Ibn Hanbal, Bukhārì, Muslim, Abū Dāwūd, Nasāìn, Darimìi and later ḥadith collections such as e.g. Ibn Kathir-khätam does not necessarily refer to the finality of the prophet Muhammad. Rather kbätam refers to: 1) a brick in a building; 2) physical sign/birthmark; 3) stamp/ring. Khätam related to finality is found in the traditions, which likely circulated later, with the motifs of 4) miracle; 5) fitna; and 6) end of days motif/shafäal intermediation in the day of judgment:

${ }^{12}$ Matthias Radscheit, Die koranische Herausforderung: Die tahaddie-Verse im Rabmen der Polemikpassagen des Korans (Berlin: Klaus Schwarz Verlag, 1996); Issa J. Boullata, “The Rhetorical Interpretation of the Qur'an: I'jāz and Related Topics," in ed. A. Rippin, Approaches to the History of the Interpretation of the Qur'an (Oxford: Clarendon Press, 1988).

${ }^{13}$ Richard Bell, A Commentary on the Qur'an, ed. Edmund Bosworth and M.E.J. Richardson (Manchester: Manchester University Press, 1991) vol. 2, p. 329. 
In the Musnad of Ibn Hanbal ${ }^{14}$ the images of all prophets are described as a building (bunyan), where Muhammad's position is that of a cornerstone (fa ana tilk labinab). See also the collection of Muslim in kitab Fad̄'ill and that of Tirmidhi in kitäb Manäqib.

In the same work, ${ }^{15}$ khatam is also meant to be the Prophet's birth mark, located on his back (zahr), which Abū Zayd, his companion, accidently touched. His fingers felt the khatam al-nubuwwa, which was surrounded by the hairs between the shoulders (sha'ra' bayn katafayh). See also Bukhārì in kitāb adab, wudu, mardă, Tirmidhi in kitab manāqib.

Abū Dāwūd in his Sunan, k. khatam ${ }^{16}$ reports that the Prophet sent some letters to foreigners and made a khätam (stamp) from fidda (silver), engraved with the words: Muhammad rasūl Allāh. This khätam was inherited by Abū Bakr, 'Umar, and 'Uthmān.

The meaning of khatam, from the very beginning, does not necessarily refer to the finality of prophethood. ${ }^{17}$ But, it refers to a physical sign, stamp, seal, etc. The meaning of khatam as finality of prophethood, came into circulation later, when there were civil wars,

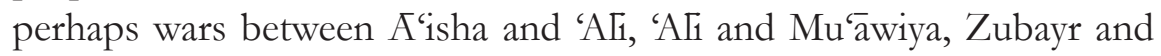
Marwan, 'Umayya and 'Abbāsiya. The emergence of false prophets has to be related to the story of civil disturbance in the early Muslim community, where dynasty comes after dynasty, caliph after caliph, 'amir after 'amir, revolt after revolt. The khätam doctrine referring to finality must have arisen in this context. During these disturbances some rebel leaders claimed to be prophets, such as al-Mukhtār, whom his adversaries accused of being a false prophet and liar, as no prophet came after Muhammad.

I have examined the isnäd (the chain of transmission) of many khätam traditions. The most reliable among them, in terms of the strands of sanad, is the physical sign (birthmark), followed by the brick building.

\footnotetext{
${ }^{14}$ Aḥmad ibn Hanbal, Musnad (Beirut: Dār Ṣādir, n.d.) vol. 2, p. 398.

${ }^{15}$ Ibid., vol. 5, p. 77.

${ }^{16}$ Sunan (Liechtenstein: Thesaurus Islamicus Foundation, 2000) k. khätam vol.
} 2, p. 701.

${ }^{17}$ See e.g. Yohanan Friedmann, "Finality of Prophecy in Sunni Islam", Jerusalem Studies for Arabic and Islam, 7 (1986) elsewhere; See also S. Evstatiev, "On the Perception of the Khätam al-Nabiyyin Doctrine in Arabic Historical Thought: Confirmation or Finality" in S. Leder, et. al. (eds), Studies in Arabic and Islam (Leuven: Peeters, 2002) elsewhere, pp. 455-67; especially p. 460. 
The weakest among them is khätam related to politics and stories of false prophets.

Additionally, the khatam doctrine is also used by both Umayyad and Abbāsid caliphs in order to silence those who claim prophethood after Muhammad. The challenger of Islam, who claimed prophethood, would consequently challenge the power of caliphs. Here is a quote from a letter of an Umayyad caliph, al-Wâlid II, in nominating his two sons-Hakam and 'Uthmān-as his successors.

Then God appointed His caliphs to follow in the path of Muhammad's prophetic ministry, after He had taken His prophet unto Himself, and (after) He had sealed His revelation by Muhammad, in order that His rule should be accomplished, His sunnah and His penalties established, and His precepts and laws adopted. This was done so that, by His caliphs, God might confirm Islam, by them He might consolidate its sway, by them $\mathrm{He}$ might strengthen its ties, by them He might safeguard its sanctities, (and) by them He might administer justice amongst His servants and might maintain the common wealth in His lands." [italics mine ${ }^{18}$

We can also find similar content in the letters of other Umayyad and Abbāsid caliphs.

\section{The Forgotten Prophets}

The following figures, Umayya ibn Abỉ Salt, Abū 'Amir, Ṭulayḥa, Aswad, Sajāh and Musaylima, who were contemporaries of Muhammad, also claimed to be prophets. There were also several claimants after Muhammad, e.g. al-Mukhtār, al Hārith ibn Så̄d, Muhammad ibn Sa’id al-maslūb, Muqanna, Maḥmūd ibn al-Faraj al-Nisābūrì, 'A「i ibn Muhammad. It is noteworthy that the above claimants were historical persons, whereas 25 of the messengers and apostles mentioned by the Qur'an are mythical figures. This is not surprising when one considers the fact that the Qur'an often employs metaphorical or allegorical modes. Thus, historical persons, including Musaylima, Umayya, Abū 'àmir, and other Arab prophets, are often not mentioned, whereas mythical ones

${ }^{18}$ Al-Ṭabari, Tärikh vol. 7, p. 220; The History, trans. Carole Hillenbrand, p. 108. For more on the discussion of the letter, see Patricia Crone and Martin Hinds, God's Caliph, p. 120; see also T. Nagel, Rechtleitung und Kalifat: Versuch über eine Grundfrage der islamischen Geschichte (Bonn: Selbstverlage des Orientalischen Seminars der Universität, 1975), pp. 82-3. 
serving as archetypes are highlighted.

Later sira and tärikh literature perpetuated the way the Qur'an narrates this. The following is the way in which Ibn Khaldun narrates the story of some claimants of prophethood:

Having performed the Farewell pilgrimage, the Prophet [may God bless and give peace be upon him] took a rest. However, he complained (of his pain). The news about this then spread. Al-Aswad in Yaman took the [opportunity to claim prophethood] as mentioned; Musaylima in Yamāma and Tulayha ibn Khuwaylid from the tribe Asad did likewise. All of these proclaimed prophethood. The Prophet [may God bless and give peace be upon him] battled them by sending emissaries and letters and exhorting the people who remained faithful [Muslims] in their tribes to perform jihād. It worked in the case of al-Aswad, [as he was killed] a day before his [Prophet's] death. The [Prophet's] pain did not distract him from the duty given by God to defend His religion. The [Prophet] also sent many Arab Muslims to many areas where the [above] arch-liars (kadhdhäbin) lived. [The Prophet] also ordered the [Muslims] to perform jibäd against them [the arch-liars]. ${ }^{19}$

Here we may ask, for what reasons are these claimants called liars? Were they not prophets similar to Muhammad? Who labeled them in such a way? Why did they earn the label of liars? Did this occur during the lifetime of the Prophet or later in the Muslim literature?

\section{From polytheism to monotheism}

Classical major cities in the Arabian peninsula, such as Mecca, T⿳ắ'if, and Yamāma, were religious centers and shrines and temples were common to all of them. Classical Muslim writers report that the Meccans worshipped idols, whose names, Latta, Uzza, Hubal and Manat, are preserved in the work of al-Kalbi (kitab asnam). ${ }^{20}$ In addition, belief in supernatural beings, such as spirits, was common among the Arabs. Both pre-Islamic poetry and the Qur'an attest that the jinn was seen as a

${ }^{19}$ Ibn Khaldūn, Tärikeh Ibn Khaldūn al-Musammā bi-Kitāb al-'Tbar wa-Diwān alMubtada' wa'-Khabar fi Ayyäm al-'Arab wa'-'Ajam wa'-Barbar wa man Āsarahum min dhawi al-Sultān al-Akbar (Cairo: Maktabah al-Nahḍah, 1355/1936), vol. 2, p. 266.

${ }^{20}$ Kitāb al-Asnām, ed. Ahmad Zakì (Cairo: Matba'a al-Amiriyya, 1384/1964); trans. R. Klinke-Rosenberger, Das Götz̧enbuch (Leipzig: Harrasowitz, 1941); N. A. Faris, The Book of Idols, Being a Translation from the Arabic of Kitäb al-Asnām by Hishäm ibn al-Kalbi (Princeton: Princeton University Press, 1952). 
powerful spiritual being and there were many who believed themselves possessed by one. Due to these beliefs in the supernatural world and deities, in Arabia the concepts of sacred places and times were preserved and guarded by believers. The word used to express the taboo was hrm (haram or mahram), meaning sacred or sacrosanct, e.g. the mabram of Bilqis at Ma'rib, that of Dhū Samāwì at Timna', capital of Qabatan, and another in Jawf of Yemen.

Various Arabian temples_al-Maqāh in Ma'rib, Sayin at Shabwa and Dhū Samāwì at Yathill (modern Barāqish)—served as holy places and destinations for pilgrimages. Long before Islam, in fact, certain deeds - such as sexual relations and bringing weapons - were prohibited in the sacred months during which the pilgrimage took place. Certain tribes even bore particular responsibility for guarding these sacred places, such as Quraysh who guarded the Ka'ba in Mecca.

My thesis is that around these shrines, temples, Ka'ba, mabram, haram found in many regions of the Arabian peninsula, there were more cults, readings (qur'an), and prophets, who attempted to reconcile the local pagan values with those of Judaism and Christianity.

\section{B. Siblings of Islam}

My hypothesis is that the teachings of Umayya ibn Abi Salt, like those of other Arabian prophets, were siblings to Islam. All of these were attempts at blending the older values of Judaism and Christianity with the local Arab pagan traditions. The project of relating Islam (and the Qur'an) to Judaism and Christianity (and to the Bible) directly-as most scholars have argued-should thus be re-examined, as Islam was not a direct sibling to the two much older religions. However, Islam was a sibling to the local cults, such as those of Umayya, Abū 'Amir, Musaylima, Sajāh, Aswad, and Ṭulayhạa, who were contemporaries of Muhammad, and who served as prophets to their people and tribe.

\section{Umayya: a Short Biography}

Umayya's name is provided by many texts of Muslim literature as follows: Umayya ibn Abi Ṣalt 'Abdalla ibn Rabi'a ibn 'Awf ibn 'Uqda ibn Ghayra ibn Qussay, i.e. Thāqif. Umayya is also known as Abū Qāsim (the name of the Prophet Muhammad), Abū 'Uthman, and Abū al-Hakam. 
Umayya's mother was Ruqayya bt. 'Abd Sham ibn 'Abd Manāf, the Qurayshite, the Prophet Muhamad's tribe in Mecca.

From the beginning, there was a relationship between the two prophets: between TTāi if, Umayya's origin and Mecca, Muhammad's first town, between the Thāqif, Umayya's tribal affiliation, and the Quraysh, that of Muhammad. Note as well that the Thāqif during the Umayyad period, the first caliphal dynasty in early Islam, played a very critical role in politics, such as holding the positions of 'amir or governor. The Thāqif, in short, became the main ally of the Quraysh in holding the caliphal dynasty, the Umayyads. Some prominent governors and 'amir came from the Thāqif. Al-Hajjāj al-Thaqafi, for instance, a governor of 'Abd Mālik ibn Marwān - who restored the Ka'ba in Mecca and who played a very important role in the early codification of the Qur'an — came from Thāqif. A long poem attributed to Umayya ibn Abi Șalt was read before al-Hajjāj to lampoon his murder of one of the members of the Khārijites, the rebel party against the Umayyad faction. It is said that before his death, the victim recalled Umayya's poem on the theme of repentance, which was originally revealed before the poet's own death.

Interestingly, the Prophet Muhammad once cursed three tribes: the Quraysh, the Hanifa and the Thäqif. ${ }^{21}$ This hadith seems to voice the later antagonism in the early Muslim community, in which the three tribes were involved. Note as well that the people of Thāqif in Táa if converted to Islam very late, during the late Medinan period, after the conquest of Mecca. Thus, the Thāqif seem to hold their own beliefs. However, it is unclear whether they remained polytheists or they regarded Umayya as their prophet. One can speculate as follows. Before their defeat, the tribe of Hanifa in Yamāma also supported their own Prophet Musaylima. So did the Tamim, the Asad and the Yemenite for their own prophets. It may well be that the Thāqif also supported Umayya as their prophet. However, this conclusion is speculative. Further evidence is indeed needed.

Returning to T⿳亠丷⿵冂⿱十口𧰨 if and Mecca, these two towns were like twin, in terms of religious significance, for their temples and shrines, but different in terms of weather. T⿳亠丷⿵冂⿱十口𧰨 if is colder than Mecca, various wines and dates are reported to have grown there. During the conquest of Ța 'if by Muslim troops, the soldiers used vine trees to climb the wall.

${ }^{21}$ Al-Tirmidhī, Sunan, "K. Manāqib”, p. 992. 
Another interesting story: Umayya's sister named Fari'‘ once came to the Prophet Muhammad, who then asked her to recite her brother's poem. She did so in front of the Prophet Muhammad, who then said that her brother is one of those whom the Qur'an lampoons as trying to rival the miracle of the Qur'an (6: 93).

However, various reports preserved in the tafsirs of Tabari, ${ }^{22}$ alSuyự̂, ${ }^{23}$ and al-Tabarsi, ${ }^{24}$ said that those whom the verse lampooned were originally, Musaylima, claimant to prophethood from Yamāma, 'Abdalla ibn Abi Sharh, the Propeht Muhammad's secretary who apostatized, and Nadr ibn al-Haarith who said that what the Prophet revealed was nothing but asatitir awwatin (fairy tales) —all of whom challenged the Prophet Muhammad.

Another striking point is that Umayya's poems were considered as rivaling the Qur'an, at least the Prophet himself hints as much. Indeed, Umayya was a known poet, as al Jạhiz, a known Mu'tazile author, attested. True, Umayya came from a family of poets. Umayya's father 'Abdallah Abi Șalt was also a poet and so were Umayya's two sons, Qāsim and Rabi'a.

Umayya, as a claimant to prophethood, played a role similar to that of Musaylima, Abū 'Amir, Sajāh, Aswad, Țulayha in many respects. Due to their claims of prophethood, all of these are regarded to be antagonistic to the main figure, the Prophet Muhammad. With regard to the prophethood claimed by Umayya, on the one hand, early and later Muslim literature undermined this claim. For example, Umayya, as a 'failed prophet,' is described as being merely jealous of the prophethood of Muhammad. ${ }^{25}$ On the other hand, this literature highlights serious

${ }^{22}$ Al-Ṭabari, Jāmi' al-Bayān 'an Ta'wìl al-Qur'ān, ed. Mạ̣mūd Muhammad Shākir and Aḥmad Muḥammad Shākir (Cairo: Dār al-Ma`árif, n.d. ), vol. 11, pp. 532-8.

${ }^{23}$ al-Suyūtī, al-Durr al-Manthūr fi Tafsir al-Ma'thūr, Mukbtasar Tafsì Tarjamān alQur'ān (Beirut: Dār al-Kutub al-'Ilmiyya, 1411/1990), vol.3, pp. 55-6.

${ }^{24}$ Al-Ṭabars̄i, Majma' al-Bayān fi Tafsir al-Qur'ān (Qum: Manshūrāt Maktabat Ayat Allāh al-'Uzmāa al-Mar'ashỉ al-Najafi, 1403H/1985), vol. 7, p. 132.

${ }^{25}$ U. Rubin, "Hanafiyya and Ka"ba: an Inquiry into the Arabian Pre-Islamic Background of Din Ibrāhim” in ed. Peters, Arabs and Arabia, p. 278; Ibn Qutayba, al-Ma 'árif, ed. Tharwat 'Ukāsha (Cairo: Dār al-Kutub, 1960), p. 28; Abū al-Farāj al-Iṣbahānī, alAghāni (Beirut: Dār al-Fikr, 1390/1970) vol. 4, 127; al-'Asqalānì, al-Isāba fì Tamyìz al-S aḥāba, ed. 'ATi Muḥammad al-Bajāwi (Beirut: Dār al-Jil, 1992) vol. 1, 250; Mas‘ùui, Murüj al-Dhahab wa-Ma'ádan al-Jawhar, ed. Muḥammad Muḥy al-Din 'Abd al-Hāmid (Cairo: al-Maktaba al-Tijāriyya al-Kubrā, 1377/1958), vol. 1, pp. 70-1. 
efforts made by Umayya to pursue information concerning the matters of prophethood. In doing so, Umayya, accompanied by Abū Sufyān, the father of $\mathrm{Mu}^{\prime}$ awwiya, the founder of Umayyad dynasty, went to Shām to consult a monk on the matter of prophethood prior to the birth of Muhammad. ${ }^{26}$ Inferring from this story, these texts also seem to acknowledge that Umayya had claimed prophethood earlier than Muhammad. The relation between the Quraysh and the Thäqif, two important tribes, is also implied. Abū Sufyān a prominent Qurayshite figure was a friend to Umayya, the Thäqif prophet. This friendship was also a symbol of a later alliance of the two tribes in the two or three centuries to come. In view of the history of early Islam, it is ironic that the Qurayshites, who were the main opponents of Muhammad, later used Islam as legitimacy for their power in ruling the umma. The Thāqif, who had their own prophet, Umayya, supported this stance.

The story of Basmalla, the most famous expression which every Muslim recites no less than ten times a day, is worth presenting here. Umayya, it is said, had revealed his own version of Basmalla before Muhammad did, which reads bi'-smike allähumma.

Umayya is portrayed in early Islamic literature as among those who embraced ḩanif, which is often interpreted as the true religion of Abraham. He taught monotheism, prayed to God, forbade drinking wine, adultery, and other sinful deeds. This meaning of the hanif has long been debated in both Muslim and Western sources. But in the Arabic of the seventh century, it refers to the Monotheist movement, that is the religion of Abraham. I would rather say that this hanif was an attempt at reconciling the older values of Judaism and Christianity with local Arab traditions, as the evidence leads us to conclude.

Having embraced another version of haniff, Umayya was involved in a serious rivalry with the Prophet Muhammad, whose mission was also to restore that hanif. Returning to the rivalry between the two prophets, the Prophet, it is said, forbade recitation of Umayya's poems. In turn, Umayya stood on the side of the Quraysh against Muhammad in the campaign of Badr. It appears that these two hanif movements could not coexist. Instead, the antagonism between the adherents of both versions

${ }^{26}$ Ibn Khaldūn, Tärikh, vol. 2, p. 170; Ibn Kathìr, al-Bidāya wa'l-Nihāya (Beirut: Maktaba al-Ma`āif, 1966), vol. 2, p. 206. 
of hanif was apparent. The well-known statement made by Umayya reads as follows: "I know that the Hanafiyya is true, but I cast doubts on [that of] Muhammad (ana a'lam anna al-Hanäfyya ḥaqq, waläkin al-shakk yudākhilni fi Muhammad)."

Beware of the topos, or thematic story. The meeting of two prophets appears in the story of Musaylima, Aswad, Abu 'Amir, and Umayya. This story of the encounter between two prophets still attracts too little attention from scholars in Islam.

The meeting between Muhammad and Musaylima is as follows. Musaylima asked for a branch of a tree from the Prophet, who refused to give it. ${ }^{27}$ Aswad, who was killed in Yemen, once came with the deputation of his tribe to Muhammad in Medina. Abū 'Amir, a Medinan prophet, had debated the Prophet Muhammad concerning hanif. ${ }^{28}$ Abu 'Āmir, it is said, erected his own mosque, known as masjid Dirār (mosque of dissent), where he and his followers prayed. As for another claimant Tulayha, he converted to Islam and made bay 'a (allegiance) to Abū Bakr. ${ }^{29}$ Sajāh also annulled her claim and converted to Islam. She died in Kufa during Mu'awiya's time. ${ }^{30}$

In the meeting between Muhammad and Umayya, Muhammad read sūra Yasin, whose tone Umayya admired. Due to this, Umayya almost embraced Islam. But then during the Badr war, he saw many victims killed by the Muslim faction. Thus he composed a eulogy to the victims, and his sympathy towards Muhamamd and Islam was gone. From this story, it seems that Umayya embraced pacifism, standing against war. It is not hard to imagine that Umayya was a monk who wore musub (humble woven wool) and hated bloodshed. In fact, he was neither a political leader nor a skillful general. Due to his lack of these two skills, he did not attract many loyal followers. Thus, his hanif version did not survive. On another occasion Umayya also stood against war: "I found much destruction in our war; and the destruction leaves us unguided" he said (Hadithi 143).

${ }^{27}$ Al-Bukhārì, Șaḥiḥ, "k. maghāzì”, vol. 2, p. 873.

${ }^{28}$ Ibn 'Abd al-Barr, al-Isti' äb fi Ma'rifa al-Așhāa (Cairo: Maktaba Nahḍa, nd.) vol. 1, p. 380. See also Moshe Gil, "The Medinan Opposition to the Prophet," Jerusalem Studies for Arabic and Islam, 10 (1987), pp. 87-92. Ref. cited.

${ }^{29}$ TTabari, Tärikh, vol. 3, p. 261; trans. Donner, The History, p. 74.

${ }^{30}$ Tabari,Tarikh, vol. 3, p. 274; trans. Donner, The History, p. 97. 
In the two lines below, Umayya condemned war waged by men (Hadithi 120: 1):

As they (men) have fought against Jins and honorable men thousands times,

We see (nothing but) madness in them; and we (thus) said, do we see these wars in dreams?

Umayya is said to have run away from the Prophet Muhammad, his rival, to avoid Islam, and to have remained an unbeliever until his death. Muhammad is reported to have said that he was a amana sha'ru wa kaffara qalbuh (believer in his poems but not in his heart). This expression indeed deserves our attention. His poems, most of which contain religious messages and are in line with Islamic teachings, are acknowledged to contain the truth of Islam. But the poet remains an unbeliever. This describes the rivalry between the two prophets and proponents of hanif. What is clear is that the antagonism between the two led to the censorship of Umayya' poems even in the later Muslim literature. Many early Muslim authors admitted that what we have are only a few fragments of Umayya's poems. Thus Umayya must have said more than what is at our disposal.

However, Muslim literature describes Umayya as one who almost embraced Islam (käda yuslim). This is in line with his sha'r (poem), which contain his repentance to God. However, note that his repentance does not necessarily mean that he almost converted to Islam, but it rather indicates the religiosity of the poet who embrace hanif, and, like other claimants to prophethood, places God at the center of their teachings.

As reported by Muslim literature, Umayya composed certain forms of dua (prayers to God), to whom he asked forgiveness. The texts sound like many verses of the Quran and various hadiths (traditions). Once again, dua is usually performed by those who are pious. Often, dua stresses humbleness of man in front of the almighty God. This does not contradict the reports by Muslim authors of the piety and religious enthusiasm of Umayya.

O God, do not make me ingratitude forever; and set faith in the throne of my heart in the course of time (Hadithi 125: 7)

$\mathrm{O}$ God, do not prevent me from (entering) paradise khuldi; and $\mathrm{O}$ our Lord, make me a humble (and) compassionate (person) (Hadithi 142; cf. Q. Maryam: 47). 
O God, forgive me, (forgive) all my sins, I will humbly come to your service in the day (that you have promised to come) (Hadithi 36: 8; cf. Q. 11: 47; 26: 82)

\section{Diwān Umayya}

Both Western and Muslim scholars, whom we should thank, have collected Umayya's poem from various sources and contexts.

- Louise Cheikho (1890): 256 lines, ${ }^{31}$

- Schulthess (1911): 530 lines, ${ }^{32}$

- Bashir Yamūt (1934): 747 lines,

- Al-Satli (1974): ${ }^{33} 895$ lines, including analysis on the spurious, changed, and authentic poems. Qur'anic and Biblical citations are traced.

- Hadithi (1975): ${ }^{34} 857$ lines, including analysis on the themes, styles, and content. Qur'anic citations are also traced.

The following sources contain Umayya's poems.

\begin{tabular}{|c|c|c|}
\hline Authors & Works & Number of Lines (bayt) \\
\hline $\begin{array}{l}\text { Ibn Hishām (d. 218)- } \\
\text { Ibn Iṣhāq (d. } 153 \text { H) }\end{array}$ & Sira & 96 Sira materials \\
\hline Ibn Salām (d. $231 \mathrm{H})$ & Tabaqāt Fubūl Shu'arā' & 8 \\
\hline Jāhiz (d. $255 \mathrm{H})$ & Kitab Hayawān & $\begin{array}{l}100 \text {, mostly on moral } \\
\text { lessons }\end{array}$ \\
\hline Ibn Qutayba (d. 276) & Sha'rwa-Shu'arä', & about 8 lines \\
\hline $\begin{array}{l}\text { Ibn Dāwūd al-Zāàirīi } \\
\text { (d. 297) }\end{array}$ & Kitäb Zabra & about 72 lines \\
\hline Tabari (d. 310 H) & Tärikh & 11 lines \\
\hline $\begin{array}{l}\text { Abū Farj al-Asfihani } \\
\text { (d. 357) }\end{array}$ & Aghäni & 73 lines \\
\hline
\end{tabular}

${ }^{31}$ L. Cheikho, Wuzarā' al-Nașrānìya wa-Kuttābubā fi al-Islām (Roma: Pontificio Istituto Orientale, 1987); idem, al-Nașānīya wa-Ädäbubā bayna 'Arab al-Jāhilīya (Bayrūt: Dār al-Mashriq, 1989).

${ }^{32}$ F. Schulthess, Umajja ibn Abi ș Șalt die unter seinem Namen überlieferten Gedichtragmente gesammelt (Leipzig, 1912).

33 al-Satli, Diwān Umayya ibn Abi Șalt (Dimashq, 1974).

${ }^{34}$ al-Hadithi, Umayya ibn Abi Șalt (Baghdad, 1975); Cl. Huart, "Une nouvelle source du Qoran", in $J A$, ser. 10, vol. iv (1904). 


\begin{tabular}{|c|c|c|}
\hline Al-Maqdisi (d. 355) & Al-Bad' wa al-Tärikh & $\begin{array}{l}\text { about } 117 \text { lines, religious } \\
\text { content }\end{array}$ \\
\hline Ibn Asākir (d. 571) & Tärkh Kabir & 56 lines \\
\hline $\begin{array}{l}\text { Abi Farj al-Bașrīi (d. } \\
\text { 759), }\end{array}$ & Hamasa Basriyya & 51 lines \\
\hline Ibn Kathir (d. 774) & Bidāya wa'-Nihāya & 87 lines \\
\hline Nuwayri (d. 733) & Nihāyat al-Arab & 74 lines \\
\hline $\begin{array}{l}\text { Ibn 'Umar al-Baghdādi } \\
\text { (d. 1093) }\end{array}$ & Khizānat al-Adab & 97 lines \\
\hline Ibn Manẓūr (d. 711) & Lisān al-Arab & 78 lines \\
\hline
\end{tabular}

It is worth presenting here, some attestations made by some early Muslim authors about the existence of Umayya's poems. al-Așmā'i (d. 216) the author of Fubüla Shu'arä's said that he saw 300 lines of Umayya's shirr. Al-'Ayni (d. $855 \mathrm{H}$ ), the author of Maqāsid Nahwiya, also claimed he saw hundred lines attributed to Umayya. 'Abd al-Qādir al-Baghdādi $(1093 \mathrm{H})$ the author of Khizana, also saw them.

The following are the transmitters of Umayya's poems:

- Faría, Umayya's sister, who met the Prophet Muhammad, who then asked her to recite some of her brother's poems.

- Sharid ibn Suwayd al-Thāqafi (d. reign of Yazid ibn Mu'āwiya), who wrote a book, which did not reach us.

- Ibn 'Abbās (d. 79/70H), a known Companion of the Prophet, whose story we can find in masā'il ibn 'Asraq (which contains a conversation between Ibn 'Abbās and Ibn 'Azraq, the Kharijite rebel leader from the tribe of Hanifa in Yamāma, on some ambiguous meaning of the verses of the Qur'an). In this work, Ibn 'Azraq asked some questions of Ibn 'Abbās about some unclear words of the Qur'an. Ibn 'Abbās then answered him with reference to Umayya's poems.

What modern critics have said about the authenticity of the poems attributed to Umayya:

(1) The Poems may have served as one of the sources of the Qur'an. A. Sprenger, who seems to have read only some of Umayya's poems, gives this theory with regard to the idea that Umaya was a proponent of banif. The most prominent proponent of this theory is Clement Huart 
who, in Une nouvelle source du Qur'an, 1904, ${ }^{35}$ said that Umayya, being older than the Prophet Muhammad, as claimed by some early Muslim literature, may have served as a model for Muhammad, who likely may have taken some verses of Umayya for the composition of the Qur'an.

(2) Skeptics argue that the poems attributed to Umayya were fabricated by later Muslim scholars. This theory points to the example of Umayya being praised by the Prophet Muhammad, his rival. Umayya in this spurious poem cites the khatam doctrine, which was developed in later Muslim literature.

The most prominent scholar of this theory is Tor Andrae, (19235). ${ }^{36}$ To him most of Umayya's poems have exegetical content which reflect the tafsir of later Muslim Qur'anic hermeneutics. This skepticism has played a vital role in the later analysis of Umayya's poems. And indeed this view has contributed to the discussion and analysis of others, such as Kamanetzky, ${ }^{37}$ who cast doubt on the authenticity of most of Umayya's poems. However, Kamanetzky still argues that at least 225 lines of the poems are authentic, particularly those with religious content. Hadithi and Satli, whose diwan I consult mostly, also subscribe to this skeptical stance, even indicating less lines of authentic poems attributed to Umayya.

Total skepticism regarding Umayya's poems, as far as my reading is concerned, comes from those who have not carefully read Umayya’s poems. But those who do so, like Kamanetzky, Hadithi, Satli, Seidenticker, ${ }^{38}$ and Berg Borg, see some possibilities of their authenticity. I have contacted Prof. Seidensticker, who is now Professor at Jena Univesity, and he is happy to hear that I deal with Umayya's poems. Seidensticker also believes that some poems contain good material and may bear authentic messages from Umayya, or at least early writings from the early century of Hijra.

${ }^{35} \mathrm{Cl}$. Huart, Une nouvelle source du Qoran, in $J A$, ser. 10, vol. iv (1904).

${ }^{36}$ Tor Andrae, Mohammed sein Leben und sein Glaube (Göttingen, Vandenhoeck \& Ruprecht, 1932); Les origines de l'Islam et le Christianisme (Paris, Adrien-Maisonneuve, 1955).

${ }^{37} \mathrm{~J}$. Frank-Kamenetzky, Untersuchungen über das Verbältnis der dem Umaija ibn Abi s Salt zugeschriebenen Gedichte zum Qoran (Kirchhain: Max Schmarsow, 1911).

${ }^{38}$ T. Seidensticker, "The authenticity of the poems ascribed to Umayya Ibn Abī al-Salt," in J.R. Smart (ed.), Tradition and Modernity in Arabic Language and Literature (Richmond, 1996). 
(3) Others, like Hirsberg, ${ }^{39}$ argue that both the Qur'an and the poems of Umayya came from the same tradition. In this regard, Hirsberg 1923 disagrees with Andrae, showing parallelism between the poems and Jewish, pre-Islamic Haggada materials.

The following facts should be kept in mind:

- Some poems bear similar content and words with the Meccan verses of the Qur'an. Note that stanzas attributed to Musaylima, which I have discussed in my dissertation, which is now under consideration for publication by Peter Lang, bear similar style and content to the Meccan verses. This however needs further analysis.

- Certain hadith stories.

- Some poems follow the style of early Arabic speech, from the genre of saj, rajaz, to shirr.

- Some poems bear similarities to the Old and New Testament in terms of content and texts, as shown by Gert Borg, Satli, and Hirsberg.

- Surprisingly, Umayya's poem resembles texts other than the Bible and the Qur'an, e.g. Gilgamesh and Athrahasis. In this regard, it is very surprising and yet at the same time challenging.

The following is an example of the story of Noah, which is similar to the story found in Genesis of the Old Testament, Gilgamesh, and later genres of Muslim literature, such as qisas.

\section{Umayya (Hadithi 5: 9-11; Satli 3: 8-10):}

The dove was sent after seven days (of the flood) resulting in the unbearable destructions.

(Noah commands it), "seek whether you see any area of the earth in which the flood of water ends."

And after (the dove) rushed away, it came with a cluster of grape, (and) with the dark mud and sticking clay

39 J. W. Hirschberg, Jüdische und christliche Lebren im vor-und frübislamischen Arabien (Cracow, 1939). 


\section{Gen. 8: 6-12:}

After forty days Noah opened the window he had made in the ark and sent out a raven, and it kept flying back and forth until the water had dried up from the earth.

Then he sent out a dove to see if the water had receded from the surface of the ground.

But the dove could find no place to set its feet because there was water over all the surface of the earth; so it returned to Noah in the ark. He reached out his hand and took the dove and brought it back to himself in the ark.

He waited seven more days and again sent out the dove from the ark. When the dove returned to him in the evening, there in its beak was a freshly plucked olive leaf! Then Noah knew that the water had receded from the earth.

He waited seven more days and sent the dove out again, but this time it did not return to him.

\section{Gilgamesh tab. XI:}

145) When the seventh day arrived

146) I sent forth a dove and let (her) go

147) the dove went away and came back to me

148) there was no resting place, and so she returned.

152) (Then) I sent forth a raven and let (her) go

153) The raven went away, and when she saw that the waters and abated

\section{Tha'labi, trans. Brinner, 2002, p. 101:}

Noah sent a raven to bring him a report, but it found a corpse and fell upon it and was too busy to return. So Noah invoked fear upon it, and for that reason it is not fond of human habitation. Then he sent a dove, and it brought back an olive leaf in its beak and mud in its claws, so he knew that the land had dried up. So (Noah) gave the dove its green (collar) that encircles its neck and blessed it to feel at home and safe in houses. 


\section{Kisāî, trans. Thackson, 1978, p. 104:}

Noah rejoiced and sent out a dove, saying, "Go see how much water remains on the face of the earth." The dove passed over the east and the west and hastened to return, for Noah had charged it with haste, and said, "O Prophet of God, the earth is destroyed and likewise all the trees, except the olive, which is green as usual." Nuh had sent a raven before; but it was so slow in returning, so he sent the dove.

\section{Concluding Remarks}

Allow me to submit my early hypothesis upon reading Umayya's poems. The following are the characteristics of Umayya's poems, which are collected in the four diwans (Schulthess, al-Sat Ii, Hadithi, and Bashir Yamūt). Like the Qur'an and other early texts of Muslim literature, the poems are repetitive - the same themes, phrases and words appear in many different occasions and contexts. Some lines appear to be mere copies of other lines in a different story and context. This reminds us of the style of the Qur'an, which also repeats many words, phrases, stories, and ideas. John Wansbrough ${ }^{40}$ remarks that it may indicate the copy and paste style of the Qur'an. In fact, this repetitive style is not strange for early Muslim literature, from hadith, qissa, tärikh, tabaqät, adab, sha'r and qasida. Some ideas are mixed with others, and added by later transmitters who were also authors in themselves.

A certain story, like a snowball, flows, rolls, and grows. In the study of hadith, Joseph Schacht, Juynboll, Micheal Cook $^{41}$ and many others have remarked on this, that the later the version is, the bigger the story becomes. Likewise, the later the isnäd (the chains of transmission too) is, the more complete it becomes.

Richard Bell relates this repetitive style of the Qur'an to the chronology of its revelation. To him, this indicates insertions in the text of the Qur'an performed by later editors, who were either the Prophet himself or his secretaries. Lüling boldly sharpens this idea, saying that

${ }^{40}$ Qur'anic Studies, Sources and Methods of Scriptural Interpretation (Oxford: Oxford University Press, 1977).

${ }^{41}$ See J. Schacht "Modernism and Traditionalism in a History of Islamic Law" in Middle Eastern Studies, 1 (1965), p. 393; Marston Speight, "The Will of Sa'd ibn A. Waqqāṣ: the Growth of a Tradition”, Der Islam, 50 (1973), p. 250; cf. H. Motzki, "Dating Muslim Traditions: A Survey", Arabica 52, 2 (2005), pp. 211-2. 
the process of editing the Qur'an was not simple and started with the Prophet himself, using older material from Arabic poetry or Christian hymns. ${ }^{42}$ The editors after the Prophet continued this task. The Qur'an, for these scholars, was not like today's Qur'an.

Umayya's poems employ the same pattern and styles. We can analyze them as to which parts may have come earlier and which parts may be a copy of the early version. In other words, we may juxtapose many lines.

Note that Umayya's poems have no isnàd. So are the Qur'annic texts. Hadith criteria cannot be used here to analyze the poems. In fact, early genres of Muslim literature, such as sira, tärikh, and early hadith, bear no isnād either. Only later ḥadiths collections, e.g. Bukhārî, Muslim, Nasā̄i and others, show more complete isnàd.

The style of the poems attributed to Umayya varies, from $s a j$, rajaz, and shirr. In shir, Umayya's poem follow different metre (bahr), such as wafir, munsarih, basit, khafif, mutaqärib, etc. However, the collectors of diwān Umayya, e.g. Bashir Yamūt, Sați and Hadithi, seem to apply a strict standard of shir rstyle upon the poems. Certain reading is forced to follow the pattern of shirr. We do not have to accept their proposal.

The following is among the examples (rajas):

$\begin{array}{ll}\text { Lam tukblaq al-samä'u wa al-nujümu } & \text { wa'l-shamsu ma'abā qamaru ya'ümu } \\ \text { qaddarabu al-mubayminu al-qayyumu } & \text { wal-jasru wa'-jannatu wal-jahimu }\end{array}$

illä li-mri sha'nubu ažimu

The above reading can be changed to a more reasonable reading following the saj'style, which is often seen in the early Meccan revelations of the Qur'an. According to Nöldeke, Bell, and Neuwirth, ${ }^{43}$ the early Meccan revelations have no strict rhyme and metre. But the rhyme often changes abruptly. So does the composition.

Perhaps, due to the task of guardianship in the light of the ifjar doctrine, later authors seem to distort certain messages of Umayya and making them different from the Qur'anic style (Satri and Hadithi call this tas.hiff). This attempt seems to also obscure the prophethood of Umayya, who, according to these authors, should be seen as no more than a poet.

${ }^{42}$ Günter Lüling, Über den Urkoran, Ansätze zur Rekonstruktion der vorislamischchristlichen Strophenlieder im Koran (Erlangen: Verlagsbuchandlung Hannelore Lüling, 2004).

${ }^{43}$ A. Neuwirth, Studien zur Komposition der mekkanischen Suren (Berlin: Walter de Gruyter, 1981), p. 92. 
However, let us read the message differently, using $s a j$ 'style.

Lam tukblaq al-samä'u wa al-nujümu wa'-shams

Ma'abà qamaru ya'ümu

qaddarabu al-mubayminu al-qayyümu

wa'l-jasru wa'l-jannatu wa'l-jabimu illä li-mri sha'nubu ašimu

(Hadithi 111: 1-2)

The above reading is in line with the style of many early revelation of the Qur'an, which is characterized by a short rhyme prose, and abrupt changes in the ending.

It is interesting to see many tendencies in presenting Umayya's poems. In Masa'il ibn 'Arraq, when Ibn 'Azraq poses questions about difficult vocabularies in the Qur'ä, Ibn 'Abbās presents Umayya's poem as references. Al-Jāhiz in his Hayawān mostly preserved poems about bikma (wisdom), amthäl (moral advises), and fables. Al-Maqdisi in al-Bad' wal-Tärkh cites religious messages attributed to Umayya, with good characteristics and unique style. Abū Dāwūd in his Kitāb al-Zabra preserves poems that bear substantial similarities with the words, composition, and content of the Qur'an. Abū Dāwūd also presents lines which praise the Prophet Muhamamad. Poems attributed to Umayya found in many later adab texts follow the style of shi'r, and their literary elements are maintained. Thus each genre of literature shaped the image of Umayya and presented his works in line with their interests. Umayya then has many faces, depending on who represents him and who cite his works.

It is important here to determine Umayya's authentic characteristics. For sure, poems whose style is too Qur'anic can be suspected as being an invention of later Muslim authors. Likewise, poems whose metre strictly follows that of later Arabic poetry is also likely an invention of later adab authors. Thus, our task is to find the true characteristics of Umayya's messages, which may be defined as not too Qur'an nor too poetic, although certain characteristics of both may be contained in the poems.

However, I should warn myself here for the sake of my own further study. We should not take general rules too far or apply certain generalizations to all poems. But we should treat the poems line per line, poem per poem, case per case, like Sidney Griffith has examined the sura of the cave, al-Kahfi, which is comparable to certain Christian texts. 
Al Makin

To close this paper, I would like to use this analogy and reflection. From the earth, we see only the sun every day. What we see during the night are only stars. In fact, our sun is part of millions or billions of stars in our Milky Way galaxy. From an Islamic perspective, and Islamic studies, Muhammad is the only prophet. In fact, there were many more prophets and Umayya is only one of them. Although his cult died out, due to his lack of political and leadership skills, attracting no significant number of followers, some of his teachings seem to endure in Islam, which absorbed many other traditions, from Judaism, Christianity, Manichaeism, paganism, Mazdaism, and others. 


\section{BIBLIOGRAPHY}

Abū al-Farāj al-Iṣbahānì, al-Aghānì, Beirut: Dār al-Fikr, 1390/1970.

Abū Dāwūd, Sunan, Liechtenstein: Thesaurus Islamicus Foundation, 2000.

Aḥmad ibn Ḥanbal, Musnad, Beirut: Dār Șādir, n.d.

al-'Asqalāni, al-Ișāba fi Tamyìz al-Ṣaḥāba, ed. 'AГi Muḥammad al-Bajāwi, Beirut: Dār al-Jil, 1992.

al-Balādhurì, Kitāb Futūụ al-Buldān, ed. Șalāḥ al-Din al-Munajjid, Cairo: Maktabat al-Nahḍa al-Mișriyya, n.d.

al-Hadithi, Umayya ibn Abi Șalt. Baghdad, 1975.

al-Kisā̄i, Qisas al-Anbiyă, ed. I, Eisenberg-Leiden: Brill, 1922-3. trans.

W. M. Thackson Jr. as The Tales of the Prophet of al-Kisäi, Boston: Twayne Publishers, 1978.

al-Mas'ūdi, Murüj al-Dhahab wa Ma'ádan al-Jawhar, ed. Muḥammad Muḥy al-Din 'Abd al-Hāmīd, Cairo: al-Maktaba al-Tijāriyya al-Kubrā, $1377 / 1958$.

al-Nuwayri, Nihāyat al-Arab fi Funūn al-Adab, ed. Muhammad Abū Fạ̣l Ibrāhìm, Cairo: al-Hay'a al-Mișriyya al-'̄Àmma li’l-Kitāb, 1975.

al-Satli, Diwān Umayya ibn Abi Șalt, Dimashq, 1974.

al-Suyūtị, al-Durr al-Manthür fi Tafsir al-Ma'thür, Mukbtasar Tafsir Tarjamān al-Qur'ān, Beirut: Dār al-Kutub al-'Tlmiyya, 1411/1990.

al-Ṭabarî, Jämi' al-Bayān 'an Ta'wil al-Qur'àn, ed. Maḥmūd Muhammad Shākir and Aḥmad Muhammad Shākir, Cairo: Dār al-Ma‘̄àrif, n.d.

----, Tärikeh al-Rusul wa'-Mulūk, ed. Muḥammad Abū al-Fạ̣l Ibrāhim, Cairo: Dār al-Ma‘ārif, 1962.

al-Ṭabarì, Majma' al-Bayān fi Tafsir al-Qur'an, Qum: Manshūrāt Maktabat Āyat Allāh al-'Uzmā al-Mar'ashì al-Najafi, 1403H/1985. al-Ya'qūbi, Tärikh al-Ya'qübi,. Najaf: al-Haydariyya, 1384/1964.

Andrae, Tor, Mohammed sein Leben und sein Glaube, Göttingen: Vandenhoeck \& Ruprecht, 1932; Les origines de l'Islam et le Christianisme, Paris: AdrienMaisonneuve, 1955.

Bell, Richard, A Commentary on the Qur'an, ed. Edmund Bosworth and 
M.E.J. Richardson, Manchester: Manchester University Press, 1991. Boullata, Issa J, “The Rhetorical Interpretation of the Qur'an: I'jaz and Related Topics," in A. Rippin (ed.), Approaches to the History of the Interpretation of the Qur'an, Oxford: Clarendon Press, 1988.

Cheikho, L., Wuzarà' al-Nașānìya wa-Kuttäbubä fi al-Isläm, Roma: Pontificio Istituto Orientale, 1987.

----, al-Nasrānìya wa-Ādäbubā bayna 'A rab al-Jäbilìya, Bayrūt: Dār al-Mashriq, 1989.

Evstatiev, S, "On the Perception of the Khatam al-Nabiyyin Doctrine in Arabic Historical Thought: Confirmation or Finality" in S. Leder, et. al. (eds.), Studies in Arabic and Islam, Leuven: Peeters, 2002.

Frank-Kamenetzky, J., Untersuchungen über das Verbältnis der dem Umaija ibn Abi s Salt zugeschriebenen Gedicbte zum Qoran, Kirchhain: Max Schmarsow, 1911.

Friedmann, Yohanan, "Finality of Prophecy in Sunni Islam”, Jerusalem Studies for Arabic and Islam, 7 (1986).

Gil, Moshe "The Medinan Opposition to the Prophet", Jerusalem Studies for Arabic and Islam 10 (1987).

Hirschberg, J. W., Jüdische und christliche Lehren im vor-und frübislamischen Arabien, Cracow, 1939.

Huart, Cl., "Une nouvelle source du Qoran”, in $J A$, ser. 10, vol. iv (1904).

Ibn al-Athìr, al-Kāmil fill-Tärìkh, Beirut: Dār Șādir, 1385/1965.

Ibn al-Kalbī, Kitāb al-Asnām, ed. Aḥmad Zakỉ, Cairo: Matba'a al-Amiriyya, 1384/1964; trans. R. Klinke-Rosenberger, Das Götz̧enbuch, Leipzig: Harrasowitz, 1941; N. A. Faris, The Book of Idols, Being a Translation from the Arabic of Kitāb al-Asnam by Hishām ibn al-Kalbi, Princeton: Princeton University Press, 1952.

Ibn Hishām, al-Sìra al-Nabawiyya, ed. Muștafāa al-Saqāa, Ibrāhìm al-Abyārì and 'Abd al-Hāfiz Shalbỉ, Cairo: Shirka wa Matba'a al-Bābi Muștafā al-Halabi wa Awlāduh, 1375/1955; trans. A. Guillaume., The Life of Muhammad, a Translation of Isḥāq's Sirat Rasül Alläh, Karachi: Oxford University Press, 1996. 
Ibn Kathir, al-Bidāya wa'-Nihāya, Beirut: Maktaba al-Ma'ārif, 1966.

Ibn Khaldūn, Tärikh Ibn Khaldūn al-Musammà bi-Kitäb al-Tbar wa-Diwàn al-Mubtada' wa'-Khabar fi Ayyäm al-'Arab wa'-'Ajam wa'-Barbar wa man $\bar{A}$ sarahum min dhawi al-Sultān al-Akbar, Cairo: Maktabah al-Nahḍah, 1355/1936.

Ibn 'Abd al-Barr, al-Isti 'áb fi Ma'rifa al-Aș̣āb, Cairo: Maktaba Nahḍa, nd.

Lüling, Günter, Über den Urkoran, Ansätze zur Rekonstruktion der vorislamischchristlichen Strophenlieder im Koran, Erlangen: Verlagsbuchandlung Hannelore Lüling, 2004.

Motzki, H. "Dating Muslim Traditions: A Survey", Arabica 52, 2 (2005).

Nagel, T., Rechtleitung und Kalifat: Versuch über eine Grundfrage der islamischen Geschichte, Bonn: Selbstverlage des Orientalischen Seminars der Universität, 1975.

Neuwirth, A., Studien zur Komposition der mekkanischen Suren, Berlin: Walter de Gruyter, 1981.

Noth, Albrecht, Quellenkritische Studien zu Themen, Formen und Tendenzen Frühislmischer Geschichtüberlieferung, Teil 1: Themen und Formen, Bonn: Selbtsverlag des Orientalischen Seminars der Unviersität Bonn, 1973.

Radscheit, Matthias, Die koranische Herausforderung: Die tabaddie-Verse im Rabmen der Polemikpassagen des Korans, Berlin: Klaus Schwarz Verlag, 1996.

Rubin, U., "Hanafiyya and Ka'ba: an Inquiry into the Arabian Pre-Islamic Background of Din Ibrāhim" in Peters (ed.), Arabs and Arabia 278.

Ibn Qutayba, al-Ma'aririf, ed. Tharwat 'Ukāsha, Cairo: Dār al-Kutub, 1960.

Schacht, J. "Modernism and Traditionalism in a History of Islamic Law" in Middle Eastern Studies 1 (1965).

Schulthess, F., Umajja ibn Abi ș Salt die unter seinem Namen überlieferten Gedichtfragmente gesammelt, Leipzig, 1912.

Seidensticker, T. "The authenticity of the poems ascribed to Umayya Ibn Abī al-Ṣalt," in J.R. Smart (ed.), Tradition and Modernity in Arabic Language and Literature, Richmond, 1996.

Speight, Marston, "The Will of Sa'd ibn a. Waqqās: the Growth of a Tradition”, Der Islam 50 (1973). 


\section{Al Makin}

Wansbrough, John, Qur'anic Studies, Sources and Methods of Scriptural Interpretation, Oxford: Oxford University Press, 1977. 